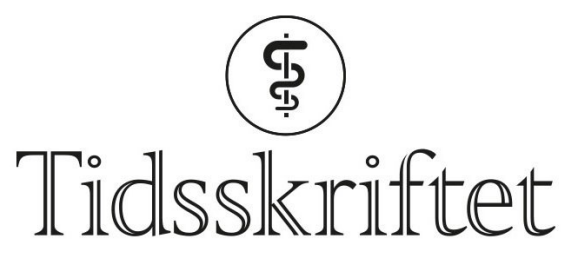

DEN NORSKE LEGEFORENING

\title{
Tarmbakterier bedrer type 2-diabetes
}

FRA ANDRE TIDSSKRIFTER

HAAKON B. BENESTAD

Universitetet i Oslo

Tarmmikrobiota som produserer kortkjedede fettsyrer fra kostfibre, kan forbedre glukosehomøostasen ved type 2-diabetes.

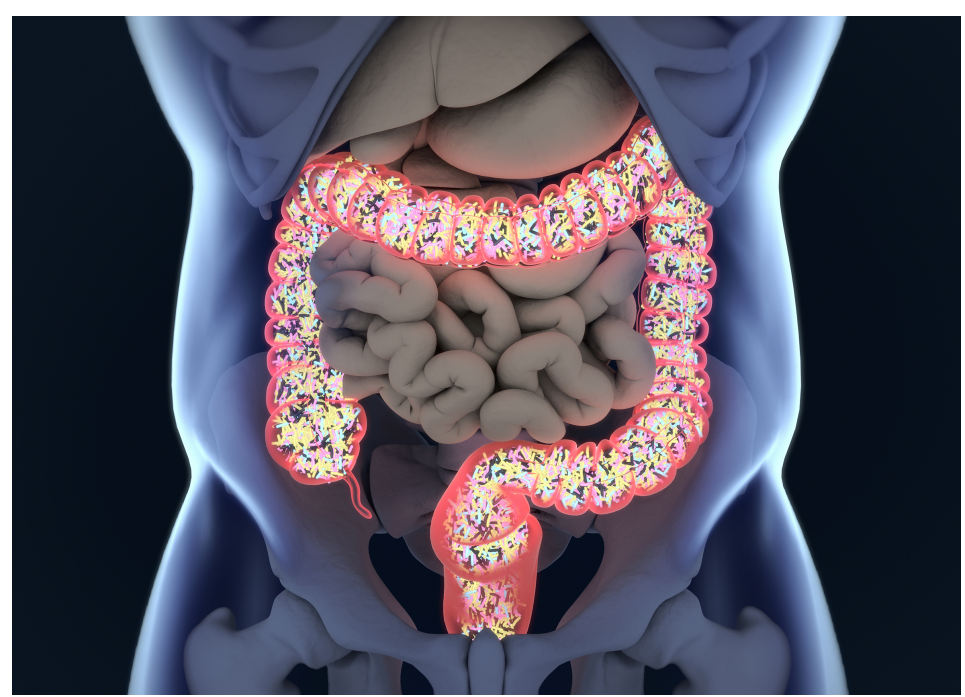

Man kan forbedre type 2-diabetes ved å hemme opptaket av karbohydrater. Illustrasjonsfoto: iStock/ChrisChrisW

Karbohydrater i kostfibre som vi ikke selv kan fordøye, kan brytes ned til kortkjedede fettsyrer av bakterier i tykktarmen. Fettsyrene kan ha hormonlignende virkninger ved å påvirke type 2-diabetes, blant annet via økt glukagonlignende peptid-1-produksjon, som stimulerer insulinsekresjonen. Men hundrevis av bakteriearter kan lage slike fettsyrer, og kostfiberfors $\varnothing \mathrm{k}$ har gitt svært variable resultater ved diabetes.

I en randomisert, kontrollert diettstudie ble pasienter med type 2-diabetes satt på fiberholdig kost (testgruppen) eller kost som ved ordinær oppfølging (kontrollgruppen) (1). Alle fikk i tillegg en amylasehemmer som gjorde deler av stivelsen i dietten ufordøyelig, og dermed til substrat for mikrobene i tarmen.

Etter 84 dager viste måling av glykert hemoglobin forbedret diabeteskontroll i begge gruppene, men mest i testgruppen, der også effekten på kroppsvekt og blodlipidprofil var best. En analyse av tarmmikrobiomet med gensekvensering i fecesprøver viste at det $\mathrm{i}$ testgruppen var 15 bakteriestammer som produserte acetat og butyrat og undertrykte andre bakteriearter med negativ effekt. 
- Normalt skal bakteriene i colon tyne de siste rester av energi ut av tarminnholdet. For å greie dette samarbeider de under anaerobe forhold, med stor artsrikdom, forklarer Arnold Berstad, som er pensjonert professor ved Universitetet i Bergen. - Et problem med denne studien er at det sammen med fiberproduktene ble gitt en amylasehemmer som påførte pasientene malabsorpsjon - i den hensikt å øke mengden substrat for produksjon av fettsyrene. Dette endrer fullstendig den økologiske likevekten, med lavere krav til artsrikdom og anaerobisitet (hvilket studien viser), sier Berstad.

- At malabsorpsjon kan bedre type 2-diabetes, er ikke noe nytt, sier han. Han påpeker at metformin, som har vært brukt som diabetesbehandling i mange år, stimulerer veksten av en gunstig bakterie som det er lite av ved type 2-diabetes. - Den aktuelle studien tyder altså på at tarmbakterier kan forbedre type 2-diabetes, men vi bør kunne greie dette uten å $\emptyset$ delegge det normale økosystemet, mener han.

\section{LITTERATUR:}

1. Zhao L, Zhang F, Ding X et al. Gut bacteria selectively promoted by dietary fibers alleviate type 2 diabetes. Science 2018; 359:1151 - 6. [PubMed][CrossRef]

Publisert: 28. mai 2018. Tidsskr Nor Legeforen. DOI: 10.4045/tidsskr.18.0279

(C) Tidsskrift for Den norske legeforening 2020. Lastet ned fra tidsskriftet.no 